\title{
PEMANFAATAN LIMBAH IKAN DAN SISA MAKANAN UNTUK PELET PAKAN IKAN DI WISATA DELTA FISHING SIDOARJO
}

\author{
Siska Desti Rahayu, Demes Nurmayanti, Fitri Rokhmalia
}

\begin{abstract}
Delta Fishing is a fishing ponds and family recreation areas located in Sidoarjo Regency. Activities at Delta Fishing generate untreated fish wastes and food leftovers, leading to problems such as odor around the site. The purpose of this study was to utilize fish wastes and leftovers* for fish feed pellets in Delta Fishing of Sidoarjo Regency. This study was a pre-experiment using the posttest-only design. Objects were subjected to several treatments and pretests by utilizing the fish wastes and leftovers as raw materials for the manufacture of fish feed pellets for gouramis of $5-15 \mathrm{~cm}$ in size. Each sample treatment was replicated 5 times and subjected to laboratory tests to determine the contents of protein in the fish pellets. Results showed that the fish pellets made from fish wastes had an average protein content of $59.2 \%$ and those made from leftovers had $32 \%$. There was a difference in the average protein content of pellets made from fish wastes and those made from leftovers with a $p$-value of $(0.000<0.05)$. Conclusion of this study, fish pellets with good protein contents derived from leftovers with a protein content of 32\%, in contrast to those made from fish wastes with a protein content of 59.2\%. The management of Delta Fishing is recommended to use the findings of the present study to evaluate and solve waste generation that may lead to the inconvenience of visitors and residents around Delta Fishing.
\end{abstract}

Keywords $\quad$ : Fish wastes and leftovers, fish pellets.

\section{PENDAHULUAN}

Besarnya penduduk dan keragaman aktivitas di kota metropolitan di Indonesia seperti Jakarta, mengakibatkan munculnya persoalan dalam pelayanan prasarana perkotaan, seperti masalah sampah. Diperkirakan hanya sekitar $60 \%$ sampah di kota besar di Indonesia yang dapat terangkut ke Tempat Pemrosesan Akhir (TPA). Sebagian besar timbulan sampah kota di indonesia adalah tergolong sampah organik. Sampah organik untuk kota besar bisa mencapai $70 \%$ dari total sampah, dan sekitar $28 \%$ sampah anorganik dan sisanya (sekitar 2\%) tergolong B3 yang perlu dikelola tersendiri (Damanhuri, $2010: 8$ ).

Teknologi pemanfaatan sampah diantaranya sebagai pupuk organik (kompos), bahan baku pembuatan batako, makanan ternak dan pembuatan pakan ikan. Satu diantara teknologi pemanfaatan sampah adalah pelet, baik untuk ikan ataupun ternak. Pelet ikan merupakan salah satu jenis pakan ikan. Ikan membutuhkan zat gizi yang digunakan untuk menghasilkan tenaga, mengganti sel-sel tubuh yang rusak dan juga untuk tumbuh. Zat gizi yang dibutuhkan adalah protein, lemak, karbohidrat, vitamin, dan mineral. Pada umumnya ikan membutuhkan makanan yang kadar protein (20-60\%), lemak (4-18\%), karbohidrat (10-50\%), vitamin dan mineral yang disesuaikan dengan jenis ikan dan kebutuhan zat gizi yang dibutuhkan (Mujiman, 2001 : 105).

Sumber sampah dapat berasal dari tempat umum dan perdagangan, diantaranya adalah (tempat pemancingan, wisata, pasar, hiburan, dll). Wisata Delta Fishing di Sidoarjo merupakan bagian dari tempat umum dan perdagangan. Wisata Delta Fishing merupakan wahana di bidang kolam pancing dan tempat rekreasi yang memiliki (fasilitas outbound, kolam renang, gazebo, warung lesehan, tempat bermain anak, tempat pemancingan dll.). Di kolam pemancingan ini terdapat ikan patin, ikan bawal, ikan gurami, ikan nila, dan ikan mas (tombro). Pengunjung di wahana wisata ini untuk hari biasa rata-rata 300 orang, sedangkan hari libur pengunjung bisa mencapai 2000 2500 orang. Berdasaran hasil studi pendahuluan sampah yang berupa sisa makanan belum ada pengolahan lebih lanjut sedangkan untuk limbah ikan mati dari kolam pancing biasanya langsung dibuang ke sungai dekat lokasi sehingga menimbulkan bau yang tidak sedap disekitar sungai yang sering mendapat komplain dari masyarakat sekitar dan para pengunjung terutama di dekat lesehan. Pengelola wisata delta fishing menganjurkan untuk mengolah limbah ikan dan sisa makanannya untuk mengurangi timbulan limbah yang dihasilkan.

\section{METODE PENELITIAN}

Jenis penelitian yang digunakan dalam penelitian ini adalah rancangan praeksperimen dengan design penelitian posttest only design karena dalam rancangan ini pada objek penelitian dilakukan beberapa perlakuan, hanya tidak terdapat kontrol dan tidak dilakukan 
pretest. dengan memanfaatkan limbah ikan dan sisa makanan sebagai bahan baku utama dalam pembuatan pelet ikan gurami ukuran $5-15 \mathrm{~cm}$. Tiap sampel dilakukan pengulangan (replikasi) sebanyak 5 kali dan dilakukan uji laboratorium untuk mengetahui kandungan gizi protein pada pelet ikan.

\section{HASIL DAN PEMBAHASAN}

1) Kandungan gizi protein pelet ikan berbahan baku limbah ikan

Pelet ikan dibuat dengan campuran bahan baku utama berupa limbah ikan dan bahan tambahan seperti tepung terigu, dedak halus, dan tepung kepala udang. Limbah ikan jika tidak dikelola dengan baik akan menimbulkan pencemaran akibat dari proses pembusukan protein ikan. Selain itu bisa menjadi sumber penyakit menular terhadap manusia karena limbah ikan selain sebagai sumber protein dengan asam amino yang baik, limbah ikan juga merupakan sumber mineral dan vitamin. Pembuatan pelet ikan sebanyak $5 \mathrm{~kg}$ dibutuhkan limbah ikan sebanyak $1,5 \mathrm{~kg}$, tepung terigu $1 \mathrm{~kg}$, dedak halus $1 \mathrm{~kg}$, dan tepung kepala udang $1,5 \mathrm{~kg}$. Pelet ikan jadi dilakukan pemeriksaan laboratorium untuk mengetahui kandungan gizi protein pada pelet ikan.
Dapat diketahui dari tabel 1 dibawah bahwa rata-rata kandungan gizi protein pelet berbahan baku limbah ikan sebesar 59,2 \%. yang berarti bahwa pelet ikan tersebut memenuhi standart SNI 7473:2009 tentang pakan buatan untuk ikan gurami. Kandungan protein pelet ikan gurami berdasarkan SNI 7473:2009 minimal sebesar 32\% untuk ukuran ikan $5 \mathrm{~cm}-15 \mathrm{~cm}$.

Menurut Sahwan (2001 : 51) dijelaskan bahwa dari berbagai referensi kandungan protein limbah ikan sebesar 20,80 - 45,09\%. Sedangkan menurut Ghufran (2007 : 112) dijelaskan bahwa kandungan protein tepung terigu sebesar $8,9 \%$. Kandungan protein dedak halus sebesar 9,6 - 10,86 \% (Sahwan, 2001 : 54). Kandungan protein tepung kepala udang sebesar 53,94 \% (Mujiman, 2001 : 117). Kandungan protein berbagai jenis bahan baku baik bahan baku utama maupun bahan baku tambahan mempengaruhi besarnya kandungan protein pelet ikan.

Dari hasil uji statistik 2 kelompok independen sampel T-test didapatkan nilai $p=0,000$ lebih kecil dari a 0,05, maka $\mathrm{H}_{0}$ ditolak, yang berarti ada perbedaan antara pelet berbahan baku limbah ikan dengan pelet berbahan baku limbah sisa makanan

Tabel 1

Hasil Kandungan Protein Pelet Limbah Ikan

\begin{tabular}{ccc}
\hline No & Replikasi Penelitian & Pelet Limbah Ikan (\%) \\
\hline 1. & R1 & 58,67 \\
\hline 2. & R2 & 59,11 \\
\hline 3. & R3 & 58,79 \\
\hline 4. & R4 & 60,04 \\
\hline 5. & R5 & 59,38 \\
\hline
\end{tabular}

2) Kandungan gizi protein pelet ikan berbahan baku limbah sisa makanan

Limbah sisa makanan bila tidak dikelola dengan baik akan menimbulkan bau yang menyengat karena sisa makanan mudah sekali diuraikan oleh mikroorganisme sehingga mudah membusuk. Pelet ikan dengan bahan baku utama limbah sisa makanan dengan penambahan bahan tambahan lain seperti tepung terigu, dedak halus, dan tepung kepala udang. Hasil perhitungan dengan menggunakan metode segitiga pearson's untuk membuat $5 \mathrm{~kg}$ pelet ikan berbahan baku limbah sisa makanan dibutuhkan sisa makanan sebanyak $2 \mathrm{~kg}$, tepung terigu $0,5 \mathrm{~kg}$, dedak halus $0,5 \mathrm{~kg}$, dan tepung kepala udang $2 \mathrm{~kg}$ yang kemudian dilakukan uji laboratorium untuk mengetahui kandungan gizi protein pelet ikan.

Berdasarkan hasil pada tabel 2

dibawah, dapat dilihat bahwa rata-rata kandungan gizi protein pelet yang berbahan baku limbah sisa makanan sebesar $32 \%$. yang berarti bahwa pelet ikan berbahan baku limbah sisa makanan termasuk dalam pelet yang memenuhi standart SNI 7473:2009 tentang pakan buatan untuk ikan gurami.

Menurut Mudjiman (2012 : 194) dijelaskan bahwa kandungan kandungan protein limbah sisa makanan sebesar 21,8 \%. Sedangkan menurut Ghufran (2007 : 112) dijelaskan bahwa kandungan protein tepung terigu sebesar $8,9 \%$. Kandungan protein dedak halus sebesar 9,6 - 10,86 \% (Sahwan, 2001 : 54). Kandungan protein tepung kepala udang sebesar 53,94 \% (Mujiman, 2001 : 117). Kandungan protein berbagai jenis bahan baku baik bahan baku utama maupun bahan baku tambahan mempengaruhi besarnya kandungan protein pelet ikan. 
Dari hasil uji statistik 2 kelompok independen sampel T-test didapatkan nilai $p=0,000$ lebih kecil dari a 0,05 , maka $\mathrm{H}_{0}$ ditolak, yang berarti ada perbedaan antara pelet berbahan baku limbah ikan dengan pelet berbahan baku limbah sisa makanan

Tabel 2

Hasil Kandungan Protein Pelet Sisa Makanan

\begin{tabular}{ccc}
\hline No & Replikasi Penelitian & Pelet Limbah Sisa Makanan (\%) \\
\hline 1. & R1 & 31,31 \\
\hline 2. & R2 & 32,48 \\
\hline 3. & R3 & 31,33 \\
\hline 4. & R4 & 32,29 \\
\hline 5. & R5 & 32,21 \\
\hline & Rata - rata & 31,924 \\
\hline
\end{tabular}

\section{3) Perbedaan kandungan gizi protein pelet ikan}

Berdasarkan grafik dibawah, diketahui bahwa ada perbedaan kandungan gizi pelet antara pelet berbahan baku limbah ikan dan pelet berbahan baku limbah sisa makanan. Kandungan gizi protein tertinggi yaitu pelet berbahan baku limbah ikan dengan rata - rata kandungan proteinnya sebesar 59,2 \%. Pelet ikan berbahan baku limbah sisa makanan rata rata kandungan proteinnya sebesar 32\%.

Berdasarkan uji statistik T-test dari data kedua pelet didapatkan hasil $p$ value $(0,000)<$ 0,05 sehingga ada perbedaan rata-rata kandungan gizi protein antara pelet berbahan baku limbah ikan dengan pelet berbahan baku limbah sisa makanan. Kandungan gizi protein pelet ikan yang berbahan baku limbah ikan lebih tinggi, dengan rata - rata kandungan protein sebesar 52,9\% dibandingkan dengan kandungan gizi protein pelet yang berbahan baku dari limbah sisa makanan dengan rata rata kandungan proteinnya sebesar $32 \%$. Hal ini dikarenakan limbah ikan sendiri masih memiliki kandungan protein yang lebih tinggi dari kandungan protein limbah sisa makanan. Dalam penelitian ini limbah ikan berasal dari kolam pemancingan Delta Fishing yaitu ikan patin, ikan bawal, ikan gurami, ikan nila, dan ikan mas (tombro) yang mati mengambang di air. Limbah ikan jika tidak dikelola dengan baik akan menimbulkan pencemaran akibat dari proses pembusukan protein ikan. Selain itu bisa menjadi sumber penyakit menular terhadap manusia karena limbah ikan selain sebagai sumber protein dengan asam amino yang baik, limbah ikan juga merupakan sumber mineral dan vitamin.

Limbah sisa makanan dalam penelitian ini berasal dari sisa makanan restoran yang terdapat di Delta Fishing berupa Ialapan, sisa nasi, sisa makanan (ikan) pengunjung. Berdasarkan penelitian sebelumnya yang dilakukan oleh Yanis dkk, pada tahun 2000 menyatakan bahwa limbah sisa makanan memiliki kandungan gizi protein sebesar 10,89\%; dan penelitian yang dilakukan oleh Hapsari (2006 : 9) bahwa limbah sisa makanan kandungan proteinnya sebesar $15,29 \%$; sehingga untuk membuat pelet ikan berbahan baku limbah sisa makanan yang sesuai dengan kebutuhan gizi protein pakan ikan gurami menjadi sebesar $32 \%$, perlu penambahan bahan baku utama dengan menambahkan bahan baku lain untuk mencukupi kebutuhan kandungan gizi protein yang dibutuhkan oleh ikan gurami.

Dalam penelitian ini limbah sisa makanan lebih tepat untuk digunakan sebagai bahan baku pembuatan pelet karena limbah sisa makanan memiliki kandungan gizi protein yang berada pada kisaran kebutuhan ikan gurami yaitu $32 \%$, sehingga jika digunakan sebagai bahan utama dalam pembuatan pelet ikan, akan membuat kandungan protein pelet sesuai dengan standart SNI 7473:2009 tentang Pakan buatan untuk ikan gurami yaitu minimal sebesar $32 \%$ untuk ukuran ikan $5-15 \mathrm{~cm}$. Hal ini diperjelas dengan penelitian yang dilakukan oleh Sahwan (2001 : 10) yang menyatakan bahwa pelet ikan untuk ikan gurami yang berasal dari campuran tepung ikan, tepung bungkil kedelai, tepung bungkil kelapa, dan dedak, memiliki kandungan gizi protein sebesar 30,72 \% ; Ikan gurami yang diberi pakan dengan kandungan gizi protein $30-32 \%$ telah memberikan pertumbuhan yang paling baik. Sehingga, pelet yang berbahan baku dari sisa makanan merupakan pelet yang memiliki kandungan protein yang sesuai dengan kebutuhan gizi protein pakan untuk ikan gurami.

Menurut penelitian yang dilakukan oleh Ghufran (2007 : 37) menyatakan bahwa kekurangan protein dapat berpengaruh negatif terhadap konsumsi pakan, sedangkan pemberian protein yang cukup akan mempengaruhi pertumbuhan ikan 


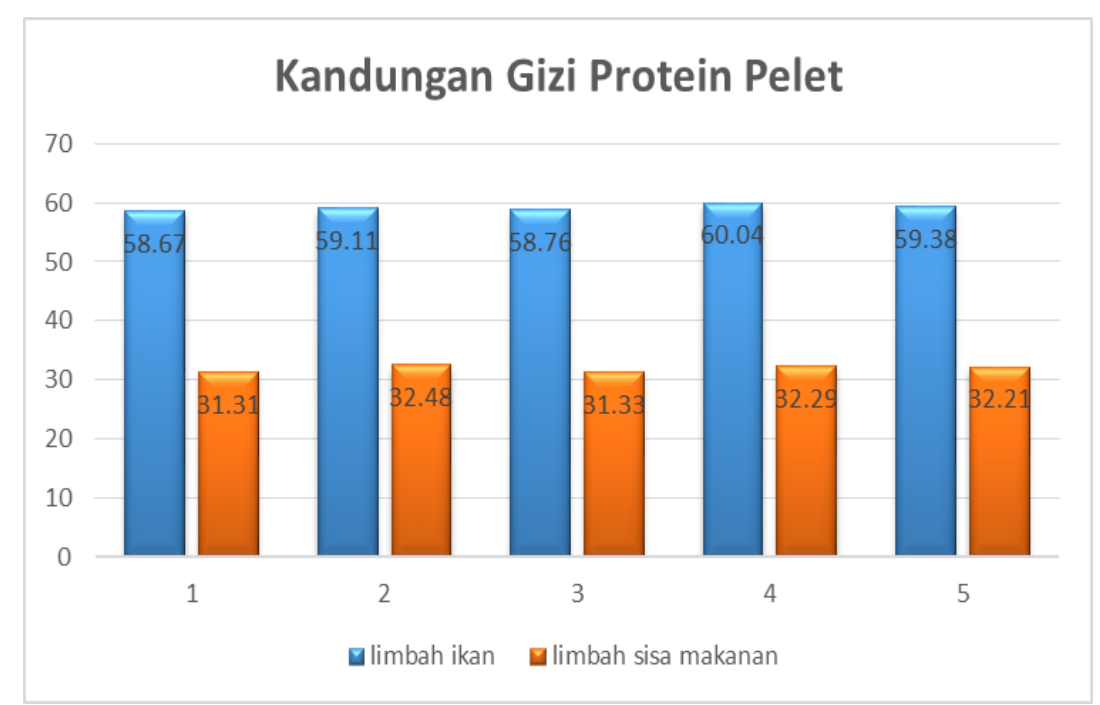

\section{KESIMPULAN}

Berdasarkan hasil penelitian, analisis, dan pembahasan yang telah dilakukan, maka dapat diambil kesimpulan bahwa pelet ikan yang memenuhi kandungan protein yang baik, berasal dari limbah sisa makanan dengan kandungan protein sebesar $32 \%$, berbeda dengan pelet yang berbahan baku dari limbah ikan yang hasil kandungan proteinnya sebesar 59,2 \%.

\section{DAFTAR PUSTAKA}

Balai Besar Pengembangan Budidaya Air Tawar., 2011. Teknik Pembenihan Ikan Gurame. Sukabumi: Kementrian Kelautan dan Perikanan

Ghufran, 2007. Meramu Pakan untuk Ikan Karnivor. Semaraang: CV Aneka Ilmu, Anggota IKAPI No. 002/JTE.

Hapsari, R. P., 2006. Energi Metabolis Dan Efisiensi Penggunaan Energi Ransum

\section{Saran}

1. Melakukan pemanfaatan limbah atau sampahnya menjadi sesuatu yang bermanfaat dan bernilai ekonomis.

2. Penelitian ini dapat dijadikan sebagai dasar peneliti lain untuk menyempurnakan penelitian yang lebih lanjut dengan mengembangkan ruang lingkup penelitian yang lebih luas dengan menggunakan metode dan bahan baku yang berbeda.

Ayam Broiler Yang Mengandung Limbah Restoran Sebagai Pengganti Dedak Padi. Bogor : Institut Pertanian Bogor.

Mujiman, A., 2001. Makanan Ikan. Jakarta: PT Penebar Swadaya.

Sahwan, F., 2001. Pakan Ikan \& Udang. Jakarta: PT Penebar Swadaya.

SNI : 7473 - 2009 tentang Pakan buatan untuk ikan gurami. 